\title{
FINANCIAL DISTRESS DENGAN LOGISTIC REGRESSION MODEL
}

\author{
Hasrul Siregar, May Handri \\ Program S1 Manajemen Sekolah Tinggi Ilmu Ekonomi (STIE) IBBI \\ Email : mayhandri@gmail.com \\ Program S1 Manajemen Sekolah Tinggi Ilmu Ekonomi (STIE) IBBI \\ Email : hasrul_siregar@yahoo.co.id
}

\begin{abstract}
ABSTRAK
Financial distress adalah merupakan suatu periode dimana perusahaan mengalami gangguan keuangan yang terjadi sebelum perusahaan mengalami kebangkrutan. Analisis terhadap financial distress sangat perlu dilakukan sejak awal untuk mengantisipasi bangkrutnya perusahaan. Perlu dikembangkan suatu model yang menggambarkan prediksi kebangkrutan suatu perusahaan melalui analisis financial distress sebuah perusahaan. Dengan mengetahui penyebab financial distress perusahaan akan lebih bersikap lebih hati-hati dalam pengambilan keputusan keuangan.

Penelitian ini bertujuan untuk menganalisis apakah-apakah faktor-faktor likuidity, financial leverage, asset utilization dan profitability dapat memprediksi financial distress perusahaan. Populasi dalam penelitian ini adalah seluruh perusahaan manufaktur yang terdaftar di Bursa Efek Indonesia. Metode pengambilan sampel dilakukan dengan metode purposive sampling dengan beberapa kriteria yang ditetapkan.

Model yang digunakan dalam penelitian ini adalah model regressi logistic yang bertujuan untuk menguji probabilitas terjadinya variabel terikat financial distress dapat diprediksi dengan variabel bebasnya yaitu likuidity, financial leverage, asset utilization dan profitabilility. Persamaan model yang dikembangkan dalam penelitian ini adalah :

$$
Y=(F D / 1-F D)=\beta_{0}+\beta_{1} X_{1}+\beta_{2} X_{2}+\beta_{3} X_{3}+\beta_{4} X_{4}
$$

Populasi dalam penelitian ini adalah seluruh perusahaan manufaktur yang terdaftar di Bursa Efek Indonesia berjumlah 136 perusahaan. Dengan criteria tertentu terpilih 50 perusahaan yang digunakan sebagai sampel. Periode penelitian tahun 2010 sd 2012.

Hasil penelitian ini menunjukkan bahwa secara simultan likuidity, financial leverage, asset utilization, profitability dapat memprediksi kondisi financial distress perusahaan. Namun secara parsial hanya variabel asset utilization dan profitability yang mampu memprediksi kondisi kebangkrutan perusahaan.
\end{abstract}

Keywords : financial, distress, logistic regression, model 


\section{PENDAHULUAN}

Krisis ekonomi telah menghancurkan sendi perekonomian ditandai dengan banyaknya perusahaan mengalami kegagalan financial. Kegagalan tersebut dominan diawali oleh kegagalan cash flow dalam penyelesaian kewajiban jangka pendek. Hal ini disebabkan oleh arus kas yang tidak stabil karena berkurangnya pendapatan penjualan yang menurun drastis pada masa krisis. Penyebab lain adalah membengkaknya jumlah hutang baik yang disebabkan oleh penambahan pinjaman dari pihak ketiga maupun yang disebabkan peningkatan kurs mata uang asing akibat melemahnya mata uang lokal. Keadaan ini mengakibatkan utilization asset menurun seiring dengan menurunya penjualan yang akhirnya perusahaan mengalami kerugian. Keadaan tersebut mengakibatkan financial distress.

Financial distress adalah merupakan suatu fase dimana perusahaan mengalami gangguan keuangan yang terjadi sebelum perusahaan mengalami kebangkrutan. Analisis terhadap financial distress sangat perlu dilakukan sejak awal untuk mengantisipasi bangkrutnya perusahaan. Perlu dikembangkan suatu model yang menggambarkan prediksi kebangkrutan suatu perusahaan melalui analisis financial distress sebuah perusahaan. Dengan mengetahui penyebab financial distress perusahaan akan lebih bersikap lebih hati-hati dalam pengambilan keputusan keuangan. Ada beberapa ciri perusahaan yang mengalami financial distress antara lain faktor tidak cukupnya modal kerja, beban hutang yang terlalu besar sehingga menimbulkan beban bunga yang cukup besar dan kerugian yang dialami perusahaan ( Rodoni dan Ali, 2010 ).

Salah satu cara yang dilakukan dalam menganalisis financial distress adalah dengan menggunakan beberapa rasio keuangan, diawali dengan penelitian yang dilakukan oleh Beaver (1966), Altman (1968), kemudian oleh Babenko (2003) dan Cheng (2006). Penelitian yang dilakukan oleh Altman ( 1984) yang merupakan penelitian awal yang menganalisis rasio keuangan untuk memprediksi kebangkrutan perusahaan. Temuannya dikenal dengan Altman Z-Score yaitu score yang dihasilkan dari hitungan standar dikalikan dengan faktor rasio keuangan yang menunjukkan tingkat kemungkinan bangkrutnya sebuah perusahaan. Penelitian Altman (2000) menghasilkan fungsi prediksi kebangkrutan untuk private firms : Z' $=0.717 \mathrm{~T}_{1}+0.847 \mathrm{~T}_{2}+3.107 \mathrm{~T}_{3}+0.420 \mathrm{~T}_{4}+0.998 \mathrm{~T}_{5}$

$\mathrm{T}_{1}=($ Current Assets - Current Liabilities $) /$ Total Assets

$\mathrm{T}_{2}=$ Retained Earnings $/$ Total Assets

$\mathrm{T}_{3}=$ Earnings Before Interest and Taxes / Total Assets

$\mathrm{T}_{4}=$ Book Value of Equity/Total Liabilities

$\mathrm{T}_{5}=$ Sales $/$ Total Assets

Chen et al ( 2006 ) menggunakan model fuzzy regression untuk memprediksi finacial distress perusahaan go-public di Taiwan. Beberapa hasil penelitiannya menunjukkan bahwa profitability dan cash flow signifikan mempengaruhi financial distress.

Penelitian ini menganalisis apakah rasio-rasio keuangan perusahaan di Indonesia bisa memprediksi financial distress. Diharapkan penelitian ini memberikan gambaran kepada perusahaan tentang apa-apa saja yang dapat mempengaruhi financial distress perusahaan.

\section{METODE PENELITIAN}

Defenisi Operasional Variabel

\begin{tabular}{|c|c|c|c|}
\hline Variabel & Defenisi Operasional & Indikator & $\begin{array}{c}\text { Skala } \\
\text { Pengukuran }\end{array}$ \\
\hline Financial Distress & $\begin{array}{lr}\begin{array}{l}\text { Keadaan } \\
\text { perusahaan }\end{array} & \text { dimana } \\
\text { mengalami } & \text { kondisi } \\
\text { kesulitan } & \text { keuangan } \\
\text { sebelum } & \text { terjadinya }\end{array}$ & $\begin{array}{l}\text { Score yang dihitung dengan } \\
\text { menggunakan persamaan Altman } \\
\text { Z-score }=\quad Z^{\prime}=0.12 \mathrm{WC} / \mathrm{TA}+ \\
0.147 \mathrm{RE} / \mathrm{TA}+0.33 \mathrm{EBIT} / \mathrm{TA}+ \\
0.006 \mathrm{MVE} / \mathrm{BVD}+0.999 \mathrm{~S} / \mathrm{TA} .\end{array}$ & $\begin{array}{l}\text { Dummy Variabel } \\
: \\
0=\text { perusahaan } \\
\text { yang mengalami } \\
\text { financial }\end{array}$ \\
\hline
\end{tabular}




\begin{tabular}{|c|c|c|c|}
\hline & $\begin{array}{l}\text { kebangkrutan atau } \\
\text { likuidasi }\end{array}$ & $\begin{array}{l}\text { Jika } Z>=2,99 \text { termasuk zona } \\
\text { aman. Jika } 1,81<Z<2,99 \\
\text { termasuk zona hijau. Jika } Z<= \\
1,81 \text { termasuk zona distress. } \\
\text { Dalam penelitian ini hanya } \\
\text { mengambil } 2 \text { kategori yaitu jika } Z \\
<=1,88 \text { tergolong perusahaan } \\
\text { yang mengalami financial } \\
\text { distress. Jika } Z>=1,88 \text { tergolong } \\
\text { perusahaan yang tidak mengalami } \\
\text { financial distress. }\end{array}$ & $\begin{array}{l}\text { distress. } \\
1=\text { perusahaan } \\
\text { yang tidak } \\
\text { mengalami } \\
\text { financial } \\
\text { distress. }\end{array}$ \\
\hline Likuiditas & $\begin{array}{l}\text { Menggambarkan } \\
\text { kemampuan } \\
\text { perusahaan untuk } \\
\text { menyelesaikan } \\
\text { kewajiban jangka } \\
\text { pendeknya dengan } \\
\text { menggunakan aktiva } \\
\text { lancar yang ada } \\
\end{array}$ & $\begin{array}{l}\text { Current Asset / Current } \\
\text { Liabilities }\end{array}$ & Rasio \\
\hline $\begin{array}{l}\text { Financial } \\
\text { Leverage }\end{array}$ & $\begin{array}{l}\text { Menggambarkan } \\
\text { struktur keuangan } \\
\text { perusahaan yang } \\
\text { menunjukkan besaran } \\
\text { hutang yang } \\
\text { digunakan untuk } \\
\text { membiayai operasi } \\
\text { perusahaan }\end{array}$ & $\begin{array}{l}\text { Total Liabilities / Total } \\
\text { Assets }\end{array}$ & Rasio \\
\hline Asset utilization & $\begin{array}{l}\text { Menggambarkan } \\
\text { seberapa besar } \\
\text { kekayaan perusahaan } \\
\text { mampu menciptakan } \\
\text { efisiensi dalam } \\
\text { pengelolaan keuangan }\end{array}$ & Sales / Total Assets & Rasio \\
\hline Profitability & $\begin{array}{l}\text { Menggambarkan } \\
\text { kemampuan } \\
\text { perusahaan untuk } \\
\text { menciptakan laba } \\
\text { dengan menggunakan } \\
\text { asset yang ada, } \\
\text { investasi ataupun } \\
\text { equity yang ada }\end{array}$ & $\begin{array}{l}\text { Net Income / Total } \\
\text { Assets }\end{array}$ & Rasio \\
\hline
\end{tabular}

Populasi dan Sampel

Populasi dalam penelitian ini adalah perusahaan manufaktur yang terdaftar pada Bursa Efek Indonesia periode 2010, 2011 dan 2012 yang berjumlah 136 perusahaan. Pengambilan sampel dalam penelitian ini menggunakan metode purposive sampling, yaitu suatu metode pengambilan sampel dengan cara menentukan sendiri criteria sampel melalui pertimbangan-pertimabangan tertentu yang memungkinkan diperoleh suatu ukuran yang efektif dalam penentuan sampel tersebut. Dalam penelitian ini, criteria yang ditetapkan adalah sebagai berikut :

1. Telah menerbitkan laporan keuangan selama peiode penelitian 2010, 2011 dan 2012. 
2. Bagi perusahaan yang masuk kategori financial distress adalah perusahaan yang telah mengalami kerugian 1 sampai 3 tahun.

3. Bagi perusahaan yang tidak mengalami financial distress adalah perusahaan yang mengalami penurunan laba selama 2 tahun.

Berdasarkan pengamatan diperoleh data-data sampel sebagai berikut :

\begin{tabular}{|l|l|l|}
\hline No & \multicolumn{1}{|c|}{ Keterangan } & \multicolumn{1}{|c|}{ Jumlah Sampel } \\
\hline 1 & $\begin{array}{l}\text { Perusahaan manufaktur yang terdaftar di BEI periode } \\
\text { 2010 sampai dengan 2012 }\end{array}$ & 136 perusahaan \\
\hline 2 & $\begin{array}{l}\text { Perusahaan manufaktur yang tidak melaporkan } \\
\text { keuangan secara berturut-turut dari tahun 2010 sampai } \\
\text { dengan 2012 }\end{array}$ & 10 perusahaan ( dikurangi ) \\
\hline 3 & $\begin{array}{l}\text { Perusahaan yang mengalami penurunan laba selama } \\
\text { satu tahun }\end{array}$ & 42 perusahaan ( dikurangi ) \\
\hline 4 & $\begin{array}{l}\text { Perusahaan yang mengalami kenaikan laba selama } \\
\text { setiap tahun 34 perusahaan ( dikurangi ) }\end{array}$ & 50 perusahaan \\
\hline & Sampel Yang Terpilih & \\
\hline
\end{tabular}

Model Analisis

Model analisis yang digunakan adalah model regressi logistic, dengan persamaan regressi :

$$
Y=(F D / 1-F D)=\beta_{0}+\beta_{1} X_{1}+\beta_{2} X_{2}+\beta_{3} X_{3}+\beta_{4} X_{4}
$$

$\mathrm{FD} \quad=$ financial distress

$\beta_{0} \quad=$ konstanta

$\beta_{1} \quad=$ koefisien likuidity $\quad \mathrm{X}_{1} \quad=$ variabel likuidity

$\beta_{2} \quad=$ koefisien financial leverage $\quad X_{2} \quad=$ variabel financial leverage

$\beta_{3} \quad=$ koefisien asset utilization $\quad X_{3} \quad=$ variabel asset utilization

$\begin{array}{llll}\beta_{4} & =\text { koefisien profitability } & X_{4} & =\text { variabel profitability }\end{array}$

\section{HASIL DAN PEMBAHASAN}

Penilaian Model Fit (Overall Model Fit Test)

Overal model fit test dilakukan untuk menguji apakah model regressi logistic yang dilakukan fit dengan data-data penelitian. Untuk menguji fit atau tidaknya model dilakukan dengan membandingkan hasil nilai -2LL awal dengan -2LL akhir. Tabel berikut menunjukkan nilai $-2 \log$ likelihood awal pada blok number $=1$ sebagai berikut :

\begin{tabular}{|ll|r|r|}
\multicolumn{4}{|c}{ Iteration Histor $\mathrm{y}^{\mathrm{a}, \mathrm{b}, \mathrm{c}}$} \\
\hline Iteration & \multirow{2}{*}{$\begin{array}{c}\text {-2 Log } \\
\text { likelihood }\end{array}$} & \multicolumn{1}{c|}{ Coefficients } \\
\cline { 4 - 4 } & & 138.628 & -1.048 \\
Step 0 & 1 & 138.317 & -1.160 \\
& 2 & 138.316 & -1.163 \\
& 3 & 138.316 & -1.163 \\
\hline
\end{tabular}

Nilai -2 log likehood akhir ( -2 LL akhir ) pada block number = 1 ditunjukkan pada table berikut : 


\begin{tabular}{|c|c|c|c|c|c|c|}
\hline \multirow[t]{2}{*}{ Iteration } & \multirow[b]{2}{*}{$\begin{array}{c}-2 \log \\
\text { likelihood }\end{array}$} & \multicolumn{5}{|c|}{ Coefficients } \\
\hline & & Constant & \begin{tabular}{|c} 
LIKUIDIT \\
$\mathrm{Y}$
\end{tabular} & $\begin{array}{c}\text { LEVERAG } \\
\text { E }\end{array}$ & $\begin{array}{l}\text { ASSET_UTIL } \\
\text { ITY }\end{array}$ & $\begin{array}{l}\text { PROFITABIL } \\
\text { ITY }\end{array}$ \\
\hline Step 1 1 & 125.620 & -1.469 & .000 & .224 & .247 & .263 \\
\hline 2 & 118.818 & -2.055 & .000 & .284 & .650 & .093 \\
\hline 3 & 116.881 & -2.228 & -.001 & .268 & .889 & .008 \\
\hline 4 & 116.314 & -2.093 & -.002 & .244 & .905 & .034 \\
\hline 5 & 116.235 & -2.022 & -.003 & .226 & .911 & .055 \\
\hline 6 & 116.234 & -2.012 & -.003 & .224 & .912 & .058 \\
\hline 7 & 116.234 & -2.012 & -.003 & .224 & .912 & .058 \\
\hline
\end{tabular}

a. Method: Enter

b. Constant is included in the model.

c. Initial -2 Log Likelihood: 138.316

d. Estimation terminated at iteration number 7 because parameter estimates changed by less than .001 . Sumber : Ouput SPSS Hasil Pengolahan Data ( 2014 )

Dari table diatas menunjukkan bahwa nilai awal ( -2 log likelihood awal -2LL ) -pada blok number $=0$ yang hanya memasukkan konstanta- mengalami penurunan dari mulai 138,628 pada step 1. Nilai 138.317 pada step 2, sampai dengan 116,316 pada step 4. Demikian juga dengan nilai iteration history yang memasukkan seluruh variable liquidity, leverage, asset utility, profitability, nilai -2 log likelihood juga mengalami penurunan dari mulai 125,620 pada step 1, mengalami penurunan 118,818 pada step 2 dan nilai 116,234 pada step 7.

Penurunan nilai -2 log likelihood pada kedua iteration history tersebut menunjukkaan bahwa model regressi logistic dinyatakan fit dengan data. ( Ghozali, 2013 )

\section{Goodness of Fit Test}

Uji goodness of fit model regressi logistic dilakukan dengan Hosmer and Lameshow Test. Hasil uji goodness of fit terlihat pada table berikut :

Hosmer and Lemeshow Test

\begin{tabular}{|l|r|r|r|}
\hline Step & Chi-square & Df & Sig. \\
\hline 1 & 8.089 & & 8 \\
\hline
\end{tabular}

Tabel ini menunjukkan bahwa besarnya nilai statistic Chi-square adalah 8,089 dengan nilai probabilitas signifikansi 0,425 jauh lebih besar dari 0,05. Menurut Ghozali (2013), jika nilai statistic Hosmer and Lemeshow lebih besar dari 0.05 maka hipotesis nol tidak dapat ditolak yang berarti model mampu memprediksi nilai observasinya, atau dapat dikatakan model dapat diterima karena cocok dengan data observasinya.

Contingency Table for Hosmer and Lemeshow Test

\begin{tabular}{|c|c|c|c|c|c|c|}
\hline & \multicolumn{2}{|c|}{$\mathrm{FD}=.00$} & \multicolumn{2}{|c|}{$\mathrm{FD}=1.00$} & \multirow[b]{2}{*}{ Total } \\
\hline & & Observed & Expected & Observed & Expected & \\
\hline \multirow[t]{8}{*}{$\overline{\text { Step } 1}$} & 1 & 13 & 12.535 & 0 & .465 & 13 \\
\hline & 2 & 10 & 11.629 & 3 & 1.371 & 13 \\
\hline & 3 & 13 & 11.184 & 0 & 1.816 & 13 \\
\hline & 4 & 11 & 10.925 & 2 & 2.075 & 13 \\
\hline & 5 & 12 & 10.738 & 1 & 2.262 & 13 \\
\hline & 6 & 11 & 10.289 & 2 & 2.711 & 13 \\
\hline & 7 & 8 & 9.766 & 5 & 3.234 & 13 \\
\hline & 8 & 8 & 9.196 & 5 & 3.804 & 13 \\
\hline
\end{tabular}




\begin{tabular}{|l|r|r|r|r|r|}
\hline 9 & 7 & 7.500 & 6 & 5.500 & 13 \\
10 & 3 & 2.237 & 6 & 6.763 & 9 \\
\hline
\end{tabular}

Sumber : Output SPSS Hasil Pengolahan Data ( 2014 )

Demikian juga dengan Contingency Table for Hosmer and Lemeshow test, dimana test bertujuan untuk memprediksi nilai observasinya. Dari table tersebut dapat dilihat dari 10 step pengamatan untuk perusahaan yang mengalami financial distress dan non financial distress tidak memiliki perbedaan yang ekstrim. Hal ini mengindikasikan bahwa model regressi logistic yang digunakan dalam penelitian ini mampu memprediksi nilai obseervasinya.

Uji Simultan

Omnibus Tests of Model Coefficients

\begin{tabular}{|ll|r|r|r|}
\hline & & Chi-square & Df & \multicolumn{1}{c|}{ Sig. } \\
\hline Step 1 & Step & 22.082 & 4 & .000 \\
& Block & 22.082 & 4 & .000 \\
& Model & 22.082 & 4 & .000 \\
\hline
\end{tabular}

Tabel diatas menunjukkan bahwa nilai signifikansi sebesar 0.000 lebih kecil dengan tingkat signifikansi 0.05. Berarti hipotesis $\mathrm{H}_{1}$ dapat diterima. Hal ini menunjukkan bahwa secara bersamasama likuidity, leverage, asset utility dan profitability mampu memprediksi terhadap kondisi financial distress perusahaan.

Uji t ( parsial)

Sama halnya dengan regressi linier, uji parsial ini dimaksud untuk melihat apakah variable bebas dapat mempengaruhi kondisi variable terikatnya.

Variables in the Equation

\begin{tabular}{|c|c|c|c|c|c|c|c|}
\hline & B & S.E. & Wald & df & Sig. & $\operatorname{Exp}(B)$ \\
\hline \multirow[t]{5}{*}{ Step $1^{\mathrm{a}}$} & LIKUIDITY & -.003 & .002 & 1.395 & 1 & .238 & .997 \\
\hline & LEVERAGE & .224 & .278 & .648 & 1 & .421 & 1.251 \\
\hline & $\begin{array}{l}\text { ASSET_UTILIT } \\
\mathrm{Y}\end{array}$ & .912 & .301 & 9.193 & 1 & .002 & 2.490 \\
\hline & $\begin{array}{l}\text { PROFITABILIT } \\
\text { Y }\end{array}$ & .058 & .666 & .008 & 1 & .030 & 1.060 \\
\hline & Constant & -2.012 & .577 & 12.151 & 1 & .000 & .134 \\
\hline
\end{tabular}

a. Variable(s) entered on step 1: LIKUIDITY, LEVERAGE, ASSET_UTILITY, PROFITABILITY.

Dari table diatas diketahui bahwa nilai signifikansi variable likuidity sebesar 0,238 lebih besar dari nilai signifikansi 0.05 yang mengindikasikan bahwa hipotesis ditolak, sehingga dapat dikatakan bahwa likuidity yang dalam penelitian ini diwakili oleh proxy current ratio ( CA/CL ) tidak dapat mempengaruhi kondisi financial distress pada perusahaan manufaktur di Bursa Efek Indonesia.

Nilai signifikansi variable leverage sebesar 0,421 lebih besar dari nilai signifikansi 0,05 yang mengidikasikan bahwa hipotesis ditolak, berarti leverage yang dalam penelitian ini diwakili oleh proxy debt to asset ratio juga tidak dapat memprediksi kondisi financial distress perusahaan.

Nilai signifikansi variable asset utility sebesar 0.002 lebih kecil dari 0,005 yang menigindikasikan bahwa hipotesis diterima, berarti variable asset utility yang dalam penelitian ini diwakili oleh SALES / TA dapat memprediksi kondisi financial distress perusahaan.

Nilai signifikansi variable profitability sebesar 0.03 lebih kecil dari 0,005 yang mengindikasikan bahwa hipotesis diterima, berarti variable profitability yang dalam penelitian ini yang diwakili oleh EBIT / TA dapat memprediksi kondisi financial distress perusahaan. 
Uji Determinasi

Uji ini dimaksudkan untuk melihat sejauh mana variable bebas mampu menjelaskan variasi variable terikat. Tabel berikut menunjukkan hasilnya :

Model Summary

\begin{tabular}{|l|c|c|c|}
\hline Step & $\begin{array}{c}-2 \log \\
\text { likelihood }\end{array}$ & $\begin{array}{c}\text { Cox \& Snell R } \\
\text { Square }\end{array}$ & $\begin{array}{c}\text { Nagelkerke R } \\
\text { Square }\end{array}$ \\
\hline 1 & $116.234^{\mathrm{a}}$ & .161 & .241 \\
\hline
\end{tabular}

Nilai Cox \& Snell R Square dimaksudkan untuk meniru ukuran $\mathrm{R}^{2}$ pada regressi linier berganda yang didasarkan pada teknik estimasi likelihood dengan nilai maksimum kurang dari 1 sehingga sulit untuk diinterpretasikan ( Ghozali, 2013 ). Nagelkerke R Square merupakan modifikasi dari koefisien $\mathrm{Cx}$ dan Snell untuk memastikan bahwa nilainya bervariasi dari 0 sampai 1 . Nilai Nagelkerke $R^{2}$ dapat diiterpretasikan seperti nilai $R^{2}$ pada multiple regression. Nilai 0.241 berarti variabilitas variable financial distress dapat dijelaskan oleh variable likuidity, leverage, asset utility, profitability sebesar $24,1 \%$.

Analisis Model Logit

Untuk mengetahui hasil uji regressi logistic dari pengaruh variable likudity, leverage, asset utility dan profitability terhadap kemampuan memprediksi kondisi financial distress dapat dilihat pada table dibawah ini.

Dari table dibawah ini dapat diperoleh persamaan regressi sebagai berikut :

$$
Y=(F D / 1-F D)=-2,012-0.003 X_{1}+0,224 X_{2}+0,912 X_{3}+0,058 X_{4}
$$

Variables in the Equation

\begin{tabular}{|c|c|c|c|c|c|c|c|}
\hline & $\mathrm{B}$ & S.E. & Wald & $\mathrm{df}$ & Sig. & $\operatorname{Exp}(B)$ \\
\hline \multirow[t]{6}{*}{ Step $1^{a}$} & LIKUIDITY & $\overline{-.003}$ & .002 & 1.395 & $\overline{1}$ & .238 & .997 \\
\hline & LEVERAGE & .224 & .278 & .648 & 1 & .421 & 1.251 \\
\hline & ASSET_UTILIT & .912 & .301 & 9.193 & 1 & .002 & 2.490 \\
\hline & $\begin{array}{l}\text { Y } \\
\text { PROFITABILIT }\end{array}$ & .058 & .666 & .008 & 1 & .030 & 1.060 \\
\hline & Y & & & & & & \\
\hline & Constant & -2.012 & .577 & 12.151 & 1 & .000 & .134 \\
\hline
\end{tabular}

Pembahasan

Berdasarkan hasil uji $\mathrm{F}$ dapat dikatakan bahwa secara serempak variable likuiditas, leverage, asset utilty dan profitability dapat memprediksi kondisi financial distress suatu perusahaan. Namun secara parsial variable likuiditas tidak signifikan, artinya likuiditas yang diwakili oleh proxy CA/CL tidak dapat memprediksi kondisi financial distress perusahaan. Dalam kaitan ini dapat dikatakan bahwa menurun atau meningkatnya rasio ini tidak dapat dijadikan alat untuk memprediksi kondisi financial distress perusahaan. Hasil penelitian ini konsisten dengan penelitian yang dilakukan oleh Mas'ud Imam (2011) namun tidak sejalan dengan penelitian yang dilakukan oleh Luciana (2003 ). Kondisi tidak signifikannya likuiditas terhadap prediksi financial distress mengindikasikan bahwa kemampuan perusahaan untuk menyelesaikan kewajiban jangka pendeknya tidaklah menjadi ukuran yang penting untuk memprediksi apakah perusahaan akan mengalami distress atau tidak. Perimbangan antara aktiva lancar dengan kewajiban lancar bukanlah suatu alat yang penting untuk memprediksi distress atau tidaknya sebuah perusahaan. Kebanyakan kajian teori menyatakan perusahaan lebih menyenangi ratio ini tinggi karena akan menggambarkan bahwa perusahaan mampu membayar kewajiban yang segera jatuh tempo. Namun disisi lain tingginya rasio ini akan menghilangkan kesempatan untuk investasi 
yang lebih meningkatkan pendapatan penjualan, sering disebut opportunity cost yang harus ditanggung. Hasil penelitian ini-yang berkaitan dengan likuiditas- sangat mendukung pendapat yang kedua : bahwa lebih baik menanamkan investasi untuk mendapatkan laba yang tinggi daripada " hanya " sekedar menjaga likuiditas.

Leverage yang diwakili oleh proxy DEBT / TOTAL ASSET juga tidak signifikan terhadap kondisi financial distress perusahaan. Dalam kaitan ini, menurun atau meningkatnya rasio hutang ini tidak dapat memprediksi kondisi financial distress suatu perusahaan. Hasil penelitian ini konsisten dengan penelitian yang dilakukan oleh Mas'ud Imam (2011). Perbedaannya adalah rasio yang digunakan oleh Mas'ud Imam adalah debt to equity ratio. Kondisi tidak signifikannya rasio hutang ini terhadap prediksi financial distress mengindikasikan bahwa besar kecilnya hutang tidak menjadi suatu ukuran penting untuk memprediksi kondisi distress atau tidaknya sebuah perusahaan. Umumnya teori-teori keuangan menyatakan bahwa besarnya hutang akan meningkatkan resiko perusahaan karena munculnya beban bunga yang tinggi yang mengakibatkan investor menginginkan return yang lebih tinggi sebagai kompensasi tingginya resiko tersebut. Namun sebenarnya resiko yang tinggi tersebut sangat disertai dengan kemungkinan untuk mendapatkan laba yang tinggi karena investasi yang lebih tinggi akan menimbulkan penjualan yang tinggi sehingga potensi laba semakin besar. Hasil penelitian ini -khususnya tidak signifikannya variabel rasio hutang - ingin menegaskan bahwa jika perusahaan menambah atau mengurangi hutang tidak akan berdampak kepada distress atau tidaknya perusahaan khususnya perusahaan-perusahaan yang tergolong perusahaan manufaktur.

Asset utility yang diwakili oleh rasio SALES / TA signifikan mampu memprediksi kondisi financial distress suatu perusahaan. Rasio ini menunjukkan kemampuan perusahaan untuk mengoptimalkan asset yang ada, salah satunya adalah mampu meningkatkan penjualan. Meningkat atau menurunnya kemampuan perusahaan dalam menciptakan penjualan akan mempengaruhi kondisi financial distress perusahaan. Hasil penelitian ini sejalan dengan penelitian Angelina (2008) dan Luciana ( 2003 ). Jika sales meningkat dapat dipastikan piutang dagang akan meningkat. Pengelolaan piutang yang baik akan menciptakan penerimaan kas yang baik pula. Penerimaan kas tersebut sudah disertai dengan laba kotor. Secara sederhana jika sales meningkat akan menciptakan piutang dagang yang disertai dengan penerimaan laba kotor. Peningkatan laba akan meningkatkan laba ditahan untuk investasi kembali. Peningkatan investasi kembali akan meningkatkan penjualan demikian seterusnya. Sehingga dapat dikatakan bahwa peningkatan dan penurunan rasio ini sangat mempengaruhi kondisi distress atau tidaknya suatu perusahaan.

Profitability menunjukkan kemampuan perusahaan dalam menciptakan laba dengan menggunakan asset yang ada. Rasio yang digunakan dalam penelitian ini adalah EBIT / TA. Semakin tinggi rasio ini menunjukkan semakin tinggi pula kemampuan asset dalam menciptakan laba kotor. Hasil penelitian menunjukkan EBIT / TA signifikan mampu memprediksi kondisi financial distress suatu perusahaan. Hasil ini sejalan dengan penelitian Chen et all (2006), Outcheva ( 2007 ), Mas'ud Imam ( 2011 ), Luciana ( 2013 ). Jika laba meningkat kemungkinan investasi akan meningkat seiring dengan peningkatan laba diatahan. Investasi meningkat akan meningkatkan pendapatan penjualan dan akhirnya kembali menciptakan laba. Jadi laba merupakan kekuatan yang paling penting dalam menentukan kondisi financial distress atau tidak nya sebuah perusahaan. Dan sebaliknya kerugian akan menciptakan peluang perusahaan mengalami distress. Setidaknya menurut Outecheva dalam disertasinya (2007) menyatakan bahwa kegagalan profitability merupakan akibat kegagalan kegagalan strategic. Dia menyebutkan bahwa penyebab level pertama distress-nya sebuah perusahaan adalah kegagalan strategic. Dimana pada saat itu perusahaan kehilangan competitive position sehingga mengakibatkan kehilangan market share yang direflesikan dengan segera kegagalan dalam perolehan laba. Keadaan ini menggambarkan sebuah transisi yang terjadi yaitu dari strategic level financial distress menjadi terjadi pada operational level. Keadaan semakin memburuk terjadi pada saat pendapatan secara permanent tidak cukup lagi menutupi biaya.

\section{KESIMPULAN}

Penelitian ini membuktikan bahwa variabel yang terbukti dapat mempengaruhi kondisi financial ditress adalah asset utility dan profitability. Sedangkan variabel likuidity dan leverage tidak terbukti dapat memprediksi kondisi financial distress 


\section{REFERENSI}

Agarwal,V., Poshakwale,S. (2006), Does Distress Risk Explain Size and Book-to-Market Effects ? Working Paper, Cranfield University School of Management, Bedford, United of Kingdom.

Ahmad Rodoni dan Herni Ali. ( 2010 ), Manajemen Keuangan, Edisi Pertama, Mitra Wacana Media, Jakarta

Altman,E. (1968), Financial Ratios, Discriminant Analysis and The Prediction of Corporate Bankruptcy, Journal of Finance, 22(4) 589-609.

Angelina, Archieliza ( 2008 ), Pengaruh Rasio Keuangan Dalam Memprediksi Kondisi Financial Distress Pada Perusahaan Manufaktur, Sekolah Tinggi Ilmu Ekonomi Perbanas, Surabaya

Babenko, I (2004), Optimal Capital Structure of The Firm in the Presence of Costs of Financial Distress, Working Paper, Hass Scholl of Business, University of Californial at Barkeley.

Beaver, W. (1996), Financial Ratio as Predictors of Failure, Journal of Accounting Research, page 71-111.

Brigham, E,F., Houston (2006), Dasar-Dasar Manajemen Keuangan, Terjemahan Ali Akbar Yulianto, Buku 1 dan 2, Edisi 10, Penerbit Salemba Empat, Jakarta

Brigham,E.F., Daves,P.R., (2010), Intermediate Financial Management, Eight Edition.

Cheng, Wen-Ying, Su, Li (2006), A Financial Distress Pre-Warning Study By Fuzzy Regression Model of Tse-Listed Company, Asian Academy of Management Journal of Accounting and Finance, Vol.2, No. 2, 75-93

Ghozali, Imam, (2013), Aplikasi Analisis, Multivariate Dengan Program SPSS 21, Edisi 7, Badan Penerbit Universitas Diponegoro, Semarang

Luciana Spica,Almilia. Kristijadi (2003), Analisis Rasio Keuangan Untuk Memprediksi Kondisi Financial Distress Perusahaan Manufaktur Yang Terdaftar di Bursa Efek Jakarta, Jurnal Akuntansi dan Auditing Indonesia (JAAI), Vol.7 No. 2, Desember 2003 ISSN :14102420 .

Mas'ud Imam (2011), Analisis Rasio Keuangan Untuk Memprediksi Kondisi Financial Distress Perusahaan Manufaktur Yang Terdaftar di Bursa Efek Indonesia, Jurnal Akuntansi Universitas Jember, hal. 139-154.

Outecheva, Natalia (2007), Corporate Financial Distress : An Empirical Analysis of Distress Risk, Dissertation No. 3430 of the University Of St. Gallen Graduate School of Business Administration, Economics, Law and Social Sciences, Difo-Druck GmbH

Platt,H., dan M.B.Platt, (2002), Predicting Financial Distress, Journal of Financial Service Profesional, $56: 12-15$.

Wahyu Widarjo, Setiawan ( 2009 ), Pengaruh Rasio Keuangan Terhadap Kondisi Financial Distress Perusahaan Otomotif, Jurnal Bisnis dan Akuntansi Vol.11, No. 2 Agustus 2009, hal. 107-119.

Whitaker,R.B. (1999), The Early Stages of Financial Distress, Journal of Economics and Finance, $23: 123-133$. 
Yuvita, Liza Maylanny (2010), Analysis of Factor Affecting The Accuracy Reporting Time Finance Companies Involved in The LQ-45 in Stock Indonesian Stock, Journal Accounting and Business. 